\title{
Factors influencing micro and small enterprise's decision to innovate in Kenya
}

\author{
Peter Njiraini ${ }^{*^{*}}$, Paul Gachanja ${ }^{2}$ and Jacob Omolo
}

\author{
* Correspondence: njiraini.peter@ku. \\ ac.ke; pgnjiraini@yahoo.com \\ 'Department of Applied Economics, \\ Kenyatta University, Nairobi, Kenya \\ Full list of author information is \\ available at the end of the article
}

\begin{abstract}
An enterprise's propensity to innovate has been recognised to have an important bearing on its performance. In Kenya empirical work on micro and small enterprises (MSEs) propensity to innovate is still nascent in spite of the pivotal role played by these enterprises in the economy. The current paper used a Probit econometric model to analyse factors that influence MSE's decision to innovate or not. Results from the analysis show that the average number of years of education for a production worker, physical capital intensity, age of an MSE, access to finance and size of an MSE are important factors influencing MSEs innovation decisions. Higher foreign ownership and manager's experience were found to act as hindrances towards MSEs' decision to innovate. Based on the study findings it is clear that human capital skills and an MSE's resource endowment positively influences MSEs innovativeness.From a theoretical perspective, there is need for skills segmentation to isolate human capital skills that are most relevant for stimulating MSEs innovative activities. Firm level and policy level strategies are also needed to improve the technical skills of the average MSEs' production workers across the country. Subsidisation of physical capital and financial services for MSEs should also be used to promote these enterprises innovativeness.
\end{abstract}

Keywords: Micro and small Enterprise, Innovation, Propensity

\section{Introduction}

Micro and small enterprises ${ }^{1}$ (MSEs) play a vital role in the Kenyan economy. These enterprises accounted for $24.6 \%$ of the country's national output in 2015. Moreover MSEs offered over 14 million employment opportunities to Kenyans in 2015 (RoK, 2016). However due to their prevalence these enterprises face stiff competition for their products and services. Surveys carried out in 1998 and 2015 highlighted inadequate markets as one to the most severe constraints facing MSEs in Kenya. In 1998 and 2015 respectively, 34 and 32\% of MSE cited inadequate market for their products (RoK, 1999; RoK 2016). One policy stance taken by the Kenyan government has been to facilitate MSEs growth by developing their technological capabilities. In spite of the effort, significantly few MSEs are yet to embrace innovation. ${ }^{2}$ According to RoK (2016) the proportion of MSEs reporting any form innovation ranged between 0.5 to $20 \%$ in 2015 .

Government policy intervention aimed at improving innovativeness among MSEs seems to presume demand-pull strategies, such as reservation of markets for MSEs products, will automatically facilitate MSEs to develop their innovativeness. Whenever

(c) The Author(s). 2018 Open Access This article is distributed under the terms of the Creative Commons Attribution 4.0 International License (http://creativecommons.org/licenses/by/4.0/), which permits unrestricted use, distribution, and reproduction in any medium, provided you give appropriate credit to the original author(s) and the source, provide a link to the Creative Commons license, and indicate if changes were made. 
the MSE innovation policies have adopted supply side strategies such as improving access to technology, the policy framework has tended to assume existence of an underlying homogenous MSE sector, which is in sharp contrast to reality. As a result, MSEs innovativeness in Kenya remain under developed, a factor that Romijn (2001) argues contributes to the low survival and growth of MSEs. As early as 1999, Aduda and Kaane (1999) posited that, over 90\% of MSEs in Kenya harboured a desire to improve their technologies through innovation.

A plethora of studies (Aghion and Howitt, 1992); Gebreeysus, 2009; Cohen and Klepper, 1996; Gebreeysus, 2009 and Robson, Haugh and Obeng, 2009) have identified age and size as some of the factors influencing enterprises decision to innovate or not. Other factors include access to human skills (Farsi and Toghree, 2014; Dutz and O'Conell, 2013 and Mañez, Rochina-Barrachina and Sanchis, 2013), managerial experience (Gebreeysus, 2009), access to finance (Farsi and Toghree, 2014; Gebreeysus, 2009; Ayyagari, et al., 2007 and Kiraka et al., 2013 and external linkages (Ayyagari, Demirgüç-Kunt and Makslmaic, 2007;. Robson, et al., 2009, Dutz and O'Connell, 2013 and Hossain, 2015).

Whereas these studies have highlighted the positive role that general human skills play towards MSEs decision to innovate, the studies fail to isolate specific areas where human skills are needed. This study thus sought to answer the question; which factors influence MSE's decision to engage in innovation activities in Kenya? The main objective of the study was, therefore, to analyse factors that influence MSEs decision to innovate with a specific focus on the production level worker skills level and managerial experience. The rest of the paper is structured as follows, Section 2 is a review of related work. Section 3 describes the study method and the data used, while Section 4 presents and discusses the results discussion of the study. Finally, Section 5 provides the main conclusions of the study as well as some recommendations.

\section{Related work}

From a theoretical perceptive, Solow (1956) and AK model by Romer (1994) emphasise physical capital accumulation and the role of embodied technology in enhancing firm innovativeness. This line of thought underlies the technology transfer movements of the 1980s. The endogenous firm growth theories by Aghion and Howitt (1992) on the other hand view innovation as part of a process of creative-destruction. Thus age of a firm is expected to influence its innovation decision whereby innovators are expected to be newly established firms (Hossain, 2015). As age increases, MSE are likely to reduce their innovation activities until much later when they have accumulated more experience through a learning process (Gebreeysus, 2009). Following Penrose (1959) resource base view, Hervas-Oliver, Sempere-Ripoll and Boronat-Moll (2014) argue that the decision to innovate in a firm is to some extent influenced by the firm's unique capabilities, its capability and dynamism in reconfiguring and sustaining its resource base.

Empirical studies by Gebreeysus (2009); Dutz and O'Conell (2013) and Mañez, Rochina-Barrachina and Sanchis (2013) found access to human skills to be a positive determinant of MSEs' decisions to innovate. Cohen and Levinthal (1990) also found skilled labour plays a facilitative role in absorption and assimilation of knowledge among firms. The experience of an enterprise manager's has also been found to influence an enterprise's propensity to innovate. Study findings by Gebreeysus (2009) found 
less experienced managers more proactive and are risk takers compared to more experienced managers. Managers with less experience are thus more likely to engage in innovation activities. With regard to firm size, Cohen and Klepper (1996), Gebreeysus (2009), and Robson, Haugh and Obeng (2009) found size of an MSE to be positive and statistically significant determinant of a firm's decision to innovate. The authors argue that relatively larger firms enjoy better access to finance and economies of scale. Literature also hightlights the role external linkages in firm's innovativess. Indeed studies by Roper et al. (1996), Love, Roper and Vahter (2014). and Dutz and O'Connell (2013) found that a firm's foreign ownership to be positively related to firm innovation decisions. Robson, et al., (2009) and Dachs, Edersberger and Loof (2007) also found MSEs' external linkages to have a positive and statistically signficant influence on a firm's decision to innovate. Studies by Ayyagari, Demirgüç-Kunt and Makslmaic (2007). Robson, et al., (2009) and Dutz and O'Connell (2013) found export linkage a positive and statistically significant determinant of a firm's innovation decision. A study be Hervas-Oliver, Sempere-Ripoll and Boronat-Moll (2014), however, found the relationship between firms' exports participation and innovativeness to be statistically insignificant.

Access to financial resources is another factor highlighted in empirical literature as having an influence on a firm's innovation propensity. Ayyagari, et al., (2007) for instance found access to external finance to be a significant and positive determinant of a firm's decision to innovate. Gebreeysus (2009) also found credit constraint to have a negative and statistically significant influence on micro-enterprises innovation capability in Ethiopia. In Kenya, Kiraka et al. (2013) also found access to finance a statistically significant determinant of the decision by an MSE to engage innovation in Kenya.

\section{Study method and data}

The current paper used the World Bank Enterprise firm level survey data for 2013. The data was collected through stratified sampling techniques. The data was nationally representative as the survey used the Kenya National Bureau of Statistics (KNBS) 2012 Census of Business Enterprises. The KNBS Census had 6147 firms that had more than five employees and another 3717 firms with five or less employees. Out of the total firms in the Census, the survey interviewed 720 firms with more than five employees and another 360 firms with five or less employees. The survey's unit of study was the physical establishment where the enterprise operators were interviewed.

The MSE data used in this study was extracted from the World Bank Enterprise Survey (ES) and the Kenya Innovation Follow-up Survey (World Bank, 2013). The two surveys contained data collected from enterprises in Kenya for the years 2010, 2011 and 2012. The Kenya Innovation Follow up survey specifically collected enterprise innovation activities. For purposes of this study, the two surveys were merged using the common enterprise identifier code referred to as "idstd". The data on MSEs was extracted by specifying for enterprises that had 1 up to 50 employees in 2010 in line with the definition of an MSE in RoK (2005).

The survey captured product, process, organizational and marketing innovation activities that MSEs engaged in during the years 2010, 2011 and 2012. Indicators for MSE growth captured in the survey included changes in number of employees and sales turnover. Data for MSEs was collected through a random stratified sampling technique, where the strata included MSE size, business sector and geographical location. The survey 
covered five regions of the country including the Central region, Nyanza region, Mombasa region, Nairobi region and Nakuru region. The firm sizes ranged from owner-employee for the micro to 10 workers/employees while small enterprises were those employing between 11 and 50 employees/workers. The data set was selected on the basis that it was the most comprehensive and recent data on MSEs' innovation in Kenya.

To analyse factors that influence the decision of an MSE to engage in innovation activities, eq. (1) was used. The decision of an MSEto innovate or not was unobservable. The result of that decision, $y_{0 i}^{*}$, was, however, observable and it took a value of one if an MSE reported that it introduced a product, process, organisational or marketing innovation new to the MSE between the years 2010 and 2012. If no innovation was reported $y_{0 \mathrm{i}}^{*}$ took a value zero. The variable $y_{0 \mathrm{i}}^{*}$ thus represents the latent unobserved endogenous variable that captures the firm's decision to innovate or not. The decision to innovate was influenced by a vector of observable independent variables summarized in $x_{0 i}$ and other unobservable variables summarized in the idyosynchronatic error term, $\varepsilon_{0 \mathrm{i}}$.

$$
y_{0 i}=\left\{\begin{array}{c}
1 \text { if } y_{0 i}^{*}=X_{0 i} \beta_{0}+\varepsilon_{0 i}>0 \\
0 \text { if } y_{0 i}^{*}=X_{0 i} \beta_{0}+\varepsilon_{0 i} \leq 0
\end{array}\right.
$$

The explanatory variables $X_{0 i}$ included were log physical capital intensity, proportion of skilled fulltime employees, average number of education years for the production worker, MSE size, age of MSE, dummy for the presence of unregistered firms' competition, dummy for mobile money use, export sales proportion, proportion of foreign ownership, manager's experience and dummies for various levels of access to finance. The coefficient $\beta_{0}$ is a vector of unknown parameters to be estimated representing the impact of certain factors on the propensity. Finally $\varepsilon_{0 \mathrm{i}}$, represents error term.

\section{Results and discussions}

From the results presented in Table 1, the estimated coefficient for average number of years of education for an MSE's production employees variable was found to be positive with a marginal effect of 0.002 . It was also found to be statistically significant at one per significance level. Thus other factors being held constant, an increase in the average number of years of education for the production employees by one year increases the probability of the MSE innovating by $0.2 \%$.

\section{Source of data: Own computation}

The results thus resonates with the study finding by Gebreeysus (2009); Dutz and O'Conell (2013) and Manez, et al., (2013) that found access to human skills to be a positive determinant of MSEs' decisions to innovate. Cohen and Levinthal (1990) also found skilled labour plays a facilitative role in absorption and assimilation of knowledge among firms. In a study of Malaysian SME innovation and firm performance Hameed, et al. (2018) found that an enterprise internal knowledge influences a firm's innovativeness. This finding gives an indication that higher human capital skills among production employees positively influence MSE decision to innovate. The finding could be interpreted in the context that the higher the level of education for the MSE production employee, the higher the employee's ability to initiate innovative activities.

The estimated coefficient for the proportion of skilled fulltime employees, on the other hand, was found to be positive but statistically insignificant. The finding corroborates that 
Table 1 Probit regression results for factors influencing MSE decision to innovate

\begin{tabular}{|c|c|c|c|c|c|}
\hline Independent variables & Coefficient & Robust Std Error & Z Value & $P$ Value & Marginal effect \\
\hline Proportion of skilled fulltime employees & 0.014504 & 0.008873 & 1.63 & 0.102 & 0.0001663 \\
\hline $\begin{array}{l}\text { Average number of education years for } \\
\text { production employee }\end{array}$ & $0.174294^{* * *}$ & 0.046809 & 3.72 & 0.000 & 0.0019984 \\
\hline Managers experience & $-0.0438^{* *}$ & 0.0210649 & -2.08 & 0.038 & -0.0005022 \\
\hline Log physical capital intensity & 0.14483 & 0.124019 & 1.17 & 0.243 & 0.0016606 \\
\hline MSE Size (2010) & $0.510995^{* *}$ & 0.248382 & 2.06 & 0.04 & 0.0058591 \\
\hline MSE Age & $-0.09324^{*}$ & 0.056209 & -1.66 & 0.097 & -0.0010691 \\
\hline MSE Age squared & $0.002007^{* *}$ & 0.001065 & 1.88 & 0.06 & 0.000023 \\
\hline Proportion of foreign ownership & $-0.02466^{* *}$ & 0.009015 & -2.74 & 0.006 & -0.0002828 \\
\hline Proportion of exports in total sales & 0.007249 & 0.007118 & 1.02 & 0.308 & 0.0000831 \\
\hline \multicolumn{6}{|c|}{ Unregistered firms competition: No (Reference) } \\
\hline Yes & -0.15245 & 0.433538 & -0.35 & 0.725 & -0.0017267 \\
\hline \multicolumn{6}{|c|}{ Access to finance: Severe obstacle (Reference) } \\
\hline Not an obstacle & $2.037606^{* *}$ & 0.813385 & 2.51 & 0.012 & 0.0102590 \\
\hline Minor obstacle & $1.038806^{*}$ & 0.559494 & 1.86 & 0.063 & 0.0084041 \\
\hline Moderate obstacle & $1.587372^{* *}$ & 0.667165 & 2.38 & 0.017 & 0.0184764 \\
\hline Major obstacle & $1.726158^{* *}$ & 0.823446 & 2.1 & 0.036 & 0.008230 \\
\hline Constant & -3.07652 & 2.138982 & -1.44 & 0.15 & \\
\hline \multicolumn{6}{|l|}{ Mobile money use: Yes (Reference) } \\
\hline No & -0.65865 & 0.665576 & -0.99 & 0.322 & -0.0085674 \\
\hline Wald $x^{2}(15)$ & $40.38^{* * *}$ & - & - & 0.0004 & \\
\hline$H-L x^{2}(3)$ & 2.5 & - & - & 0.467 & \\
\hline Pseudo $R^{2}$ & 0.4591 & - & - & - & \\
\hline Link Test: hat & 1.2374 & 0.3452 & 3.58 & 0.0000 & \\
\hline hat square & -0.10834 & 0.07008 & -1.55 & 0.122 & \\
\hline Mean VIF & 4.31 & - & - & - & \\
\hline No.of observations & 123 & - & - & - & \\
\hline
\end{tabular}

Dependant variable $=1$ if an MSE reported any (product, process, organization or marketing) innovation between 2010 and 2012 and 0 otherwise

Notes: Asterisk ${ }^{* * *}$ denotes significance at $1 \%$ level of significance $p<0.01 ;{ }^{*} 5$ denotes significance at $5 \%$ level $p<0.05$ and ${ }^{*}$ denotes significance at $10 \%$ level $p<0.1$

of Oum, Narjoko and Harvie (2014) on the positive role of access to skills level in stimulating MSEs innovation in Thailand. Overall, the findings on the importance of human capital in firm's innovation are in line with Romer's (1990) endogenous growth theory, which emphasises human capital role in technological innovations. The finding, however, seems to give an indication that it is advanced human capital skills levels for the production employees that is relatively more important in stimulating MSE innovation activities rather than the absolute numbers of skilled fulltime employees. Thus employment of more skilled fulltime employees without matching their skills levels to the varying MSEs' requirements is unlikely to stimulate innovative activities amongst MSEs.

The estimated coefficient for MSE manager's years of experience in a sector was found to be negative with marginal effect of 0.0005 and statistically significant at $5 \%$ level. Thus holding other factors constant, an increase in an MSE's manager years of experience in a particular sector by one year decreases the probability that the MSE will innovate by $0.05 \%$. This means that the higher the number of years of experience an MSE manager 
has in a particular sector, the less likely that the MSE will innovate. The finding is in agreement with the study findings by Gebreeysus (2009). Farsi and Toghraee (2014) also posit that majority of SMEs managers tend to have low education background thus run the enterprises through intuition as opposed to analytical thinking. As the enterprises grows older and more complex, such managers are ill prepared to handle more complex business decisions and likely to adopt a risk averse attitude. Thus from the result it is likely that more experienced managers tend to be complacent and do not put a premium on innovation. More experienced managers are, therefore, less likely to lead an MSE to engage in innovative activities. The result may also be a pointer to the fact that innovation activities, especially for MSEs in Kenya most of which operate in informal and poorly resourced environments, tend to be a risk taking activity whose returns are highly uncertain. Experienced MSE managers may thus be more risk averse relative to inexperienced managers and thus avoid making innovation decisions.

Size of the MSE as measured by number of fulltime employees at the beginning of the study period in 2010, was one of the factors that was found to have influenced innovation decision. Results in Table 1 show that the estimated coefficient for size of an MSE was found to be positive with a marginal effect of 0.006 and statistically significant at $5 \%$ level of significance. This finding implies that an additional employee by the MSE, other factors remaining constant, increases the likelihood that MSE will innovate by $0.6 \%$. This finding seems to suggest that MSEs that are bigger tend to have accumulated resources including human skills that facilitate them to become innovators. This finding conforms to the Resource Base theory (Penrose, 1959) where the author argues that MSEs that are relatively bigger tend to have accumulated resources that facilitate them to become innovators. Cohen and Klepper (1996), Gebreeysus (2009), and Robson, et al., (2009) also found size of the MSE to be positive and statistically significant determinant of a firm's decision to innovate. The authors argue that relatively larger firms enjoy better access to finance and economies of scale. It is also possible that the relatively bigger MSEs may be producing more than one product or service and therefore tend to report introduction of relatively higher number of new innovative products compared to smaller sized one-product MSEs.

With respect to the age of the MSE, the estimation results presented in Table 1 show that the estimated coefficient for age of MSE variable was negative with a marginal effect of 0.001067 . The coefficient was statistically significant at $10 \%$ level of significance. The coefficient for age squared variable was, however, found to be positive with a marginal effect of 0.000023 . The coefficient for age squared variable was also statistically significant at 5\% level of significance. The estimation results on MSE's age variable thus confirms that the MSE's decision to innovate and its age is a non-linear relationship. Whereas young MSEs tend to be innovativeness, as age increases they are likely to reduce their innovation activities until much later when they have accumulated more experience through a learning process. The finding was in line with the creative destructive theories by Aghion and Howitt (1992), which argue that innovation is part of a process of creative-destruction where innovators are expected to be newly established firms. Hossain (2015) also found that new enterprises adopt new innovations relative to incumbent enterprises. As age increases, MSE are likely to reduce their innovation activities until much later when they have accumulated more experience through a learning process (Gebreeysus, 2009). The results also suggests that there is an optimal age of the MSE where innovation reaches a peak. 
According to the results presented in Table 1 the estimated coefficient for proportion of foreign ownership was found to be negative with a marginal effect of 0.00028 . It was also found to be statistically significant at $1 \%$ level of significance. This means that $1 \%$ increase in the proportion of foreign ownership of an MSE decreased the probability of the MSE innovating by $0.03 \%$. The finding further implies that MSEs that have a higher proportion of foreign ownership are less likely to innovate. The finding contradicts the results by other studies such as Roper et al. (1996), Love, et al., (2014) and Dutz and O'Connell (2013). In Kenya, the finding that MSEs with higher proportion of foreign ownership are less likely to innovate may be partly because MSEs with high proportion of foreign ownership tend to be affiliates of parent firms that are incorporated abroad. Most of the innovation decisions in these firms are done centrally and tend to emanate from the foreign based parent enterprise. The local enterprise is, therefore, unlikely to initiate its own innovative activities.

Access to finance in the model was specified as categorical variable where "very severe obstacle" category was used as the reference. As shown in Table 1, the estimated coefficients for access to finance dummy variables were found to be positive and statistically significant at $5 \%$ level when the access to finance was "not an obstacle", "moderate obstacle" and "major obstacle". The marginal effects were found to be 0.01, 0.018 and 0.008, respectively and were statistically significant at $5 \%$ level. With the dummy variable "minor obstacle" the coefficient was found to be positive with marginal effect of 0.008 but statistically significant at $10 \%$ level of significance. The overall implication of the finding on access to finance was that, holding other factors constant, MSE decision to innovate was constrained by the MSEs' varying levels of as access to finance. Thus based on the estimation results presented in Table 1, reducing the severity of access to finance from "very severe obstacle" level to "not an obstacle" level increases the probability that the MSE would innovate by $1.0259 \%$. This finding resonates with the study findings by Ayyagari, et al., (2007); Gebreeysus (2009) and Kiraka, et al., (2013) that found access to finance a statistically significant determinant of the decision by an MSE to engage innovation.

To sum up, average number of years of education for an MSEs' production worker, age of an MSE, access to finance and size of an MSE are important factors influencing MSEs innovation decisions. Higher foreign ownership and long manager's experience were found to act as hindrances towards MSEs' decision to innovate. On the other hand, an MSE's physical capital intensity, unregistered firms competition, proportion of exports, the proportion of fulltime production workers and the usage of mobile money in an MSEs operations were found not to influence MSEs innovation decisions as their estimated coefficients were found to be statistically insignificant.

\section{Conclusions and recommendations}

Results from the analysis show that the average number of years of education for an MSEs' production worker, age of an MSE, access to finance and size of an MSE are important factors influencing MSEs innovation decisions. Higher foreign ownership and manager's experience were found to act as hindrances towards MSEs' decision to innovate. On the other hand, an MSE's physical capital intensity, unregistered firms competition, proportion of exports, the proportion of fulltime production workers and the usage of mobile money in an MSEs operations were found not to influence MSEs 
innovation decisions as their estimated coefficients were found to be statistically insignificant. Based on the study findings it is clear that human capital skills play a positive and statistically significant role in stimulating MSEs innovativeness and by enhancing their absorptive capacity. From a theoretical perspective, there is need for skills segmentation to isolate skills that are most relevant for stimulating MSEs innovative activities. Firm level and policy level strategies are also needed to improve the technical skills of the average MSEs' production workers across the country. Limited access to resources especially finance which curtails MSE's decision to innovate, could be handled through establishment of venture capital as advocated by Hossain (2015).

\section{Endnotes}

1. Micro enterprise includes an enterprise employing up to 10 workers whether paid or not. A Small enterprise includes an enterprise employing 11 workers up to 50 workers whether paid or not.

2. Innovation in this paper is refers to the enterprise decision to implement a new product/service, new production process, new marketing method and or new organizational practice with an aim od enhancing its performance. This definition thus encompasses product, process, organization and market innovations.

Acknowledgements

The authors acknowledge the World Bank Office in Nairobi for allowing us to use the World Bank Enterprise Data for 2013.

Funding

Not applicable.

Availability of data and materials

Data used in this study is secondary data collected by the World Bank in Kenya and is available from the World Bank Enterprise Database 2013 on request and authorisation from the World Bank.

\section{Author's contribution}

PN contributed in drafting the initial study, including literature review, methodology, obtaining data, analysing the data and initial interpretation of the results. PG contributed in interpretation of the study findings and in refining the study conclusions. JO contributed in the refining the study background, objectives and in sharpening the study findings. All authors read and approved the final manuscript.

Competing interest

Authors declare that they have no competing interest.

\section{Publisher's Note}

Springer Nature remains neutral with regard to jurisdictional claims in published maps and institutional affiliations.

\section{Author details}

${ }^{1}$ Department of Applied Economics, Kenyatta University, Nairobi, Kenya. ${ }^{2}$ Department of Economic, Theory Kenyatta University, Nairobi, Kenya

Received: 20 July 2018 Accepted: 29 November 2018

Published online: 08 December 2018

\section{References}

Aduda, K., \& Kaane, H. (1999). Technology policies and strategies. In A. Mulei \& C. Bokea (Eds.), Micro and Small Enterprises in Kenya: Agenda for Improving the Policy Environment (pp. 129-141). Nairobi: International Centre for Economic Growth (ICEG).

Aghion, P., \& Howitt, P. (1992). A model of growth through creative destruction. Econometrica, 60(2), 323-351.

Ayyagari, M., Demirgüç-Kunt, A., \& MaksImaic, V. (2007).Firm Innovation in Emerging Markets. World Bank Policy Research Working Paper No. 4157. World Bank.

Cohen, W., \& Klepper, S. (1996). Firm size and the nature of innovation within industries. The case of process and product R\&D. The Review of Economics and Statistics, 78(2), 232-243.

Cohen, W., \& Levinthal, D. (1990). Absorptive capacity: A new perspective on learning and innovation. Administrative Science Quarterly, 33(1), 128-152. 
Dachs, B., Edersberger, B., \& Loof, H. (2007). The Innovative Performance of Foreign Owned Enterprises in Small Open Economies. CESIS Electronic Working Paper Series No. 87.

Dutz, M. A., \& O'Connell, S. D. (2013). Productivity, innovation and growth in Sri Lanka: An empirical investigation. World Bank Policy Research Working Paper, no 6354. World Bank.

Farsi, J.Y and Toghraee, M.T. (2014) Identification of the main challenges of small and medium sized enterprises in exploiting innovative opportunities (case study: Iran SMEs)' journal of global entrepreneurship research 2014 4:4. Springer https:// doi.org/10.1186/2251-7316-2-4

Hameed, W., Basheer M. labal, J., Anwar., A and Ahmad, H., (2018) Determinants of Firm's open innovation performance and the role of R \& D department: An empirical evidence from Malaysian SME's. Journal of Global Entrepreneurship Research, 8:29 Springer https://doi.org/10.1186/s40497-018-0112-8

Hervas-Oliver, J. L., Sempere-Ripoll, F., \& Boronat-Moll, C. (2014). Process innovation strategy in SMEs, organizational innovation and performance: A misleading debate? Small Business Economics, 43(4), 873-886.

Hossain, M.(2015). A review of literature on open innovation in small and medium enterprises. Journal of Global Entrepreneurship Research, 5:6 springer. doi.org/10.1186/s40497-015-0022-y.

Kiraka, R., Kobia, M., \& Katwalo, A. M. (2013).Micro, small and medium enterprise growth and innovation in Kenya: A case study on the Women Enterprise Fund. Investment Climate and Business Environment Research Fund, 1-104. Trust Africa. IDRC, Nairobi, Kenya. Retrieved from https://pdfs.semanticscholar.org/bbde/ca7d03b9bb263fb76f6f56978377b19447fc.pdf

Love, J., Roper, S., \& Vahter, P. (2014). Learning from openness: The dynamics of breadth in external innovative linkages. Strategic Management Journal, 35, 1703-1716

Mañez, A., Rochina-Barrachina, E., Sanchis, A., \& Sanchis, A. (2013). Do process innovations boost SMEs productivity growth? Empirical Economics, 44(3), 1373-1405.

Oum, S., Narjoko, D., \& Harvie, C. (2014). Constraints, determinants of SME innovation and role of government support. Economic Research Institute for ASEA and East Asia (ERIA) Discussion Paper 2014-10. Retrieved from http: eria.org/ERIADP-2014-20.pdf.

Penrose, T. (1959). The theory of the growth of the firm. New York: Oxford University Press.

Republic of Kenya. (1999). National Micro and Small Enterprise baseline survey. Nairobi: Government of the Republic of Kenya.

Republic of Kenya.(2005). Sessional Paper No.2 of 2005 on Development of Micro and Small Enterprises for Wealth and Employment Creation for Poverty Creation. Nairobi: Government of the Republic of Kenya.

Republic of Kenya. (2016). Micro, Small \& Medium Establishments. Basic Report. Nairobi: Government of the Republic of Kenya.

Robson, P., Haugh, H., \& Obeng, B. (2009). Enterprenuership and innovation in Ghana: Enterprising Africa. Small Business Economics, 32, 331-350

Romer, P. (1994).The origins of endogenous growth. The Journal of Economic Perspectives, Vol. 8, No. 1, pp. 3-22: American economic association.

Romijn, H. (2001). Technology support for small-scale industry in developing countries: A review of concepts and project practices. Oxford Development Studies, 29(1), 57-76.

Roper, S., Ashcroft, B., Love, J. H., Dunlop, S., Hofmann, H., \& Vogler-Ludwig, K. (1996). Product innovation and development in UK, German and Irish manufacturing. Northern Ireland Economic Research Centre/Fraser of Allander Institute, University of Strathclyde.

Solow, R. (1956). A contribution to the theory of economic growth. The Quarterly Journal of Economics, 70(1), 65-94.

World Bank (2013).Improving firm level measurement of innovation in emerging markets and developing countries: Kenya innovation follow up survey. Retrieved from http: World bank.org.

\section{Submit your manuscript to a SpringerOpen ${ }^{\circ}$ journal and benefit from:}

- Convenient online submission

- Rigorous peer review

- Open access: articles freely available online

- High visibility within the field

- Retaining the copyright to your article

Submit your next manuscript at $\boldsymbol{\nabla}$ springeropen.com 